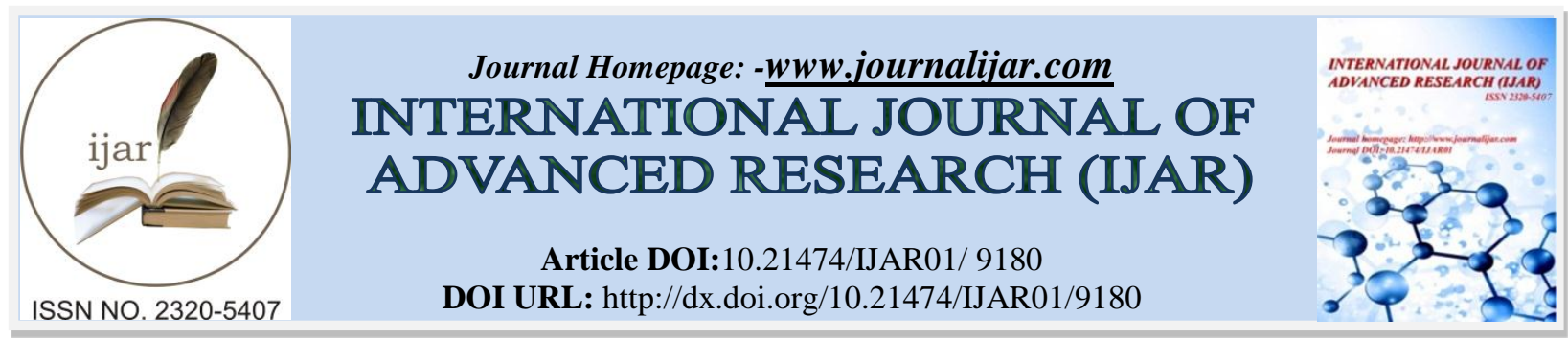

RESEARCH ARTICLE

\title{
ANALYSIS OF THE LOCAL CURRENCY SETTLEMENT AND BILATERAL INTERNATIONAL TRADE BETWEEN CHINA AND NIGERIA.
}

\begin{abstract}
Hanbo Wang.
International Business School, Gengdan Institute of Beijing University of Technology, Niulanshan, Shunyi District, Beijing 101301.
\end{abstract}

\section{Manuscript Info}

Manuscript History

Received: 26 March 2019

Final Accepted: 28 April 2019

Published: May 2019

Key words:-

China; Nigeria; local currency exchange; international trade.

\section{Abstract}

With the vertical deep development of the "Belt and Road" and the rising international status of RMB after its accession to the SDR, African countries such as Nigeria have now used the RMB as a settlement tool, which has far-reaching impact on international trade between China and African countries. This paper uses SWOT method to analyze the strengths, weaknesses, opportunities and threats of local currency settlement between China and Nigeria. Meanwhile, it uses comparative analysis method to compare the trade differences before and after the docking of RMB and Naira, and discusses the impact Sino- Nigerian local currency exchange caused on other African countries and their currencies.

Copy Right, IJAR, 2019,. All rights reserved.

\section{Introduction:-}

Historically, no reserve currency can be maintained for a long time and with the development of history, there will always be new currencies to replace it. The status of the US dollar has been declining since the 2008 financial crisis, especially under the pressure of today's trade war, many countries are trying to avoid US dollar settlement. In recent years, the RMB has developed rapidly in cross-border use and made remarkable progress in international trade and investment. It has turned into the world's second largest trade finance currency and the fifth largest payment currency. According to data released by Society for Worldwide Interbank Financial Telecommunications (SWIFT) on August 30, 2018, the proportion of RMB used in global transactions rose to $2.04 \%$ in July 2018. With the sustained development of economy, China's share of the world economy and its own economic volume keeps on growing, thus its voice and influence in the international monetary system gradually rises, which also creates opportunities for the RMB to play a more important role in the system. With the vertical deep development of the "Belt and Road" and the rising international status of RMB after its accession to SDR, economic cooperation between China and African countries has become more frequent, and trade between them has exceeded 100 billion US dollar. Nowadays Nigeria and other African countries have used the RMB as a settlement tool, which has farreaching impact on international trade between China and African countries.

\section{SWOT analysis of local currency settlement between China and Nigeria}

The background of the docking of RMB and Naira

Naira is the universal currency of Nigeria, the abbreviation of it is and it's the official currency of Nigeria. In August 2016, the Central Bank of Nigeria announced that Naira was decoupled from the US dollar and exchanged with the RMB instead. With this as a sign, the RMB has begun the hard currency course in Africa. Also in April

Corresponding Author:-Hanbo Wang.

Address:-International Business School, Gengdan Institute of Beijing University of Technology,

Niulanshan, Shunyi District, Beijing 101301. 
2016, China reached a currency swap agreement with Nigeria. The Central Bank of Nigeria deposited 65 billion yuan.

The currency exchange between China and Nigeria has affected the status of the US dollar in Africa. Since the "Belt and Road" has expanded trade between the two countries in recent years, the Chinese government and the Nigerian government hope to reduce the impact of the US dollar trade exchange through local currency swaps. Prior to this, the exchange of local currency between the RMB and the South African currency had a very significant effect.

Previously, trade between Nigeria and China was settled in US dollar. However, since the existence of currency exchange gains and losses before and after the settlement of the US dollar, a large number of swap and post-swap risks were created and costs were increased.

Up to now, Nigeria's economy is still entirely dependent on oil revenues. As oil prices fell, Naira depreciated and the country became increasingly dependent on oil. The Nigerian central bank decided that Naira would be "decoupled" from the US dollar, and the government hopes that after the exchange of RMB with Naira, Naira will return to stability.

\section{SWOT Analysis of the docking of RMB and Naira Advantages}

In 2016, the Nigerian economy suffered its first economic negative growth during more than two decades. Since 2017, economic growth has rebounded due to the expansion of oil production along with the sustained and steady growth of agriculture, but aggregate demand remains weak. In 2018, the gross domestic product (GDP) was 418.1 billion dollars, which was $1.93 \%$ year-on-year in terms of local currency .Although it has rebounded for two consecutive years, it is still far below the growth rate of around $6 \%$ before 2015. Inflation has gradually fallen from a high point, maintaining a high level of fluctuations above $11 \%$.Due to the decline of global oil price and the Nigerian government's policy of reducing unemployment, Nigeria's inflation rate soared to more than $10 \%$ from 2016 and continued climbing to $18.72 \%$ in January 2017. From February 2017 to July 2018, inflation fell to $11.14 \%$.

\section{Disadvantage}

Since July 2016, in order to support the Naira exchange rate and control inflation rate, Nigeria's policy interest rate has remained at $14 \%$, and market interest rates have increased slightly in recent years. The supply of M2 is increasing year by year, and the credit system is underdeveloped. In 2017, M2 supply was 2414.1 billion naira, an increase of 2.3\% over the same period last year. Nigeria's financial system is underdeveloped, financing costs are high and loans are relatively difficult. In 2017, domestic credit accounted for only $23.28 \%$ of GDP.

Current account surpluses generally follow changes in world oil prices. According to the National Bureau of Statistics of Nigeria, the total import and export volume of Nigerian goods in 2017 was 2,316.1 billion naira, up $33.53 \%$ year-on-year. Among them, the export volume was 1,359.8 billion naira, an increase of 1494.73\%; the import volume was 956.27 billion naira, an increase of $8.45 \%$; The trade surplus was 403.5 billion naira. With the increase in oil exports and the slight increase in oil prices in 2019, Nigeria's export earnings will increase accordingly. The scale of international reserves is increasing. Nigeria's international reserve is mainly foreign exchange reserve, and foreign exchange reserve is 43.17 billion dollars by January 2019 .

\section{Opportunities}

Since the establishment of diplomatic relations between China and Nigeria, bilateral relations have been friendly for a long time, high-level visits have been conducted frequently, and new progress has been made continuously in economic and trade cooperation. The joint construction of the "Belt and Road" between China and Africa will provide more resources and means for African development, it will also bring many opportunities for the development of Chinese-funded enterprises.

As for agriculture and agricultural machinery, both China and Nigeria are big agricultural countries, and they have strong complementarity in the field of agricultural development. Nigeria has abundant agricultural production resources and a huge consumer market for agricultural and sideline products, and its Agriculture industry accounts for about $40 \%$ of GDP. Due to the lack of technology, Nigeria is not self-sufficient in food, and China can exactly provide technical support in this field. At the same time, Nigeria has abundant mineral resources, but it has long 
been in an unreasonable state of mineral exploitation and utilization. Importing petroleum and mineral extraction equipment produced by China and other countries can improve the utilization rate of resources

\section{Threats}

It mainly comes from the internal political corruption and the effect of presidential election, as well as the negative impact on foreign-funded enterprises from the activities of external anti-government armed groups. Firstly, the effect of presidential election emerges, and political self-interest may affect the enterprise; Secondly, the problem of corruption is serious, increasing the cost of enterprises; Thirdly, the anti-government armed forces have blocked the entry of foreign enterprises and undermined foreign investment activities due to the distribution of interests. At the same time, the economy is highly dependent on oil exports, and the single economic structure makes the Nigerian economy very fragile, making Nigeria often use oil currency; the macroeconomic performance is poor, the investment environment is not clear; the external debt problem is prominent, and the enterprise may be affected; Fourthly, it is also related to foreign exchange control and exchange rate risk.

\section{Analysis of the Differences in Sino- Nigerian Trade before and after the docking of RMB and Naira Trade analysis with US dollar settlement}

According to the data of China Customs from 2014 to 2016, the bilateral trade volume between China and Nigeria has decreased from 181.1 billion dollars in 2014 to 14.94 billion dollars in 2015, down 17.2\% year-on-year, while the bilateral trade volume between China and Nigeria has again dropped to 106.2 dollars in the next year, down $28.9 \%$ year-on-year. The overall decline from 2014 to 2016 was $41.3 \%$.

Among them, China exported 15.44 billion dollars to Nigeria in 2014, imported 2.66 billion dollars from Nigeria and had a trade surplus of 12.78 billion dollars; in 2015, China exported 13.7 billion dollars to Nigeria, down $11 \%$, imported 1.24 billion dollars from Nigeria, down 53.3\%; in 2016, China exported 9.71 billion dollars to Nigeria, down 29.1\%, imported 910 million dollars from Nigeria, down 27.0\%, and had a trade surplus of 8.81 billion dollars, down $29.3 \%$

In the three years of 2014-2016, China- Nigeria trade used the US dollar for intermediate transactions. Through data comparison, the trade volume between China and Nigeria has gradually declined to a certain extent, with an average decrease of about $40 \%$.

\section{Trade analysis of RMB settlement}

According to China Customs 2016-2018 data, the bilateral trade volume between China and Nigeria has increased from 10.62 billion dollars in 2016 to 13.78 billion dollars, up $29.7 \%$ year-on-year. In the following year, the bilateral trade volume between China and Nigeria increased again to 15.27 billion dollars, up 10.8\% year-on-year.

Among them, in 2016, China exported 9.71 billion dollars to Nigeria, imported 910 million dollars from Nigeria and had a trade surplus of 8.81 billion dollars. In 2017, China exported 12.16 billion dollars to Nigeria, up 25.1\%, imported 1.62 billion dollars from Nigeria, up 79.1\%, and had a trade surplus of 10.53 billion dollars, up $19.5 \%$ year on year. In 2018, China exported 13.41 billion dollars to Nigeria, up 10.3\%, imported 1.86 billion dollars from Nigeria, up $14.6 \%$, and had a trade surplus of 11.55 billion dollars, up $9.6 \%$ year on year.

Statistics on trade between China and Nigeria are shown in Table 1.

Table 1:-Statistics of bilateral trade between China and Nigeria in recent years Unit: \$100 million

\begin{tabular}{|l|l|l|l|l|l|}
\hline Trade situation & 2014 & 2015 & 2016 & 2017 & 2018 \\
\hline Import trade volume & 26.6 & 12.4 & 9.1 & 16.2 & 18.6 \\
\hline Export volume & 154.4 & 137 & 97.1 & 121.6 & 134.1 \\
\hline Balance of trade surplus & 127.8 & 124.6 & 88.1 & 105.3 & 115.5 \\
\hline Bilateral trade volume & 181 & 149.4 & 106.2 & 137.8 & 152.7 \\
\hline
\end{tabular}

\section{Overall analysis}

China's import trade with Nigeria in recent years is shown in Figure 1, and export trade in Figure 2, trade surplus in Figure 3, bilateral trade in Figure 4. 


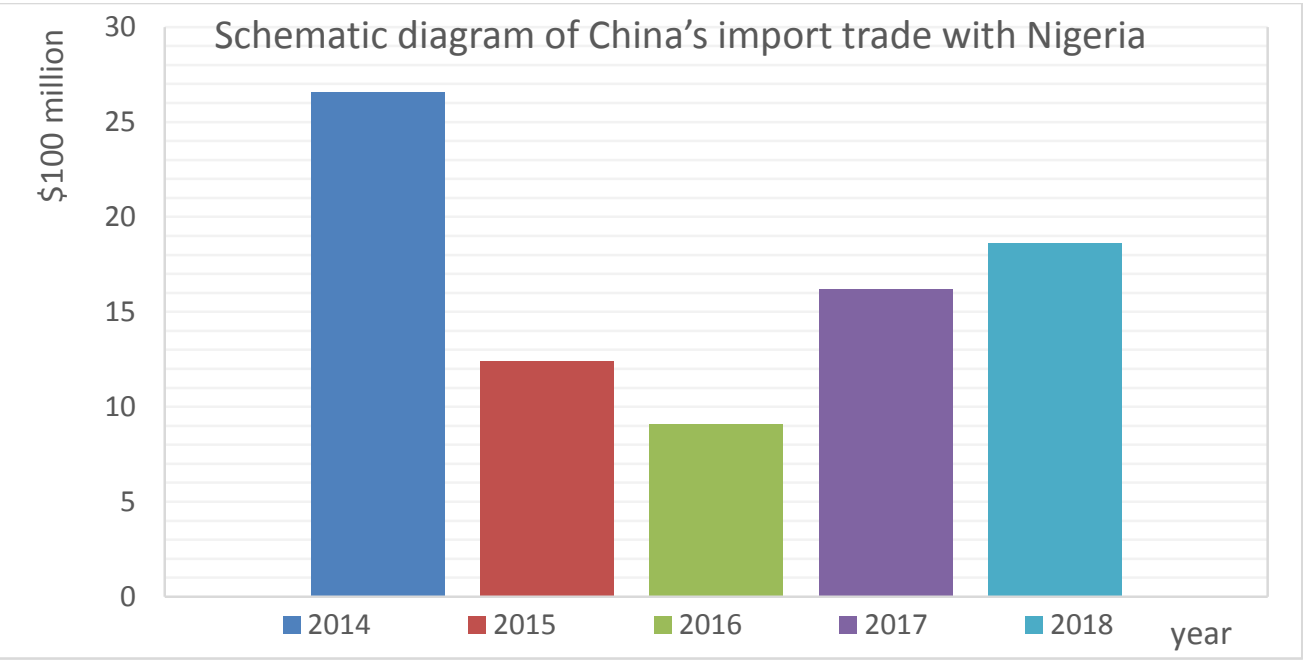

Fig 1:-Schematic diagram of China's import trade with Nigeria in recent years

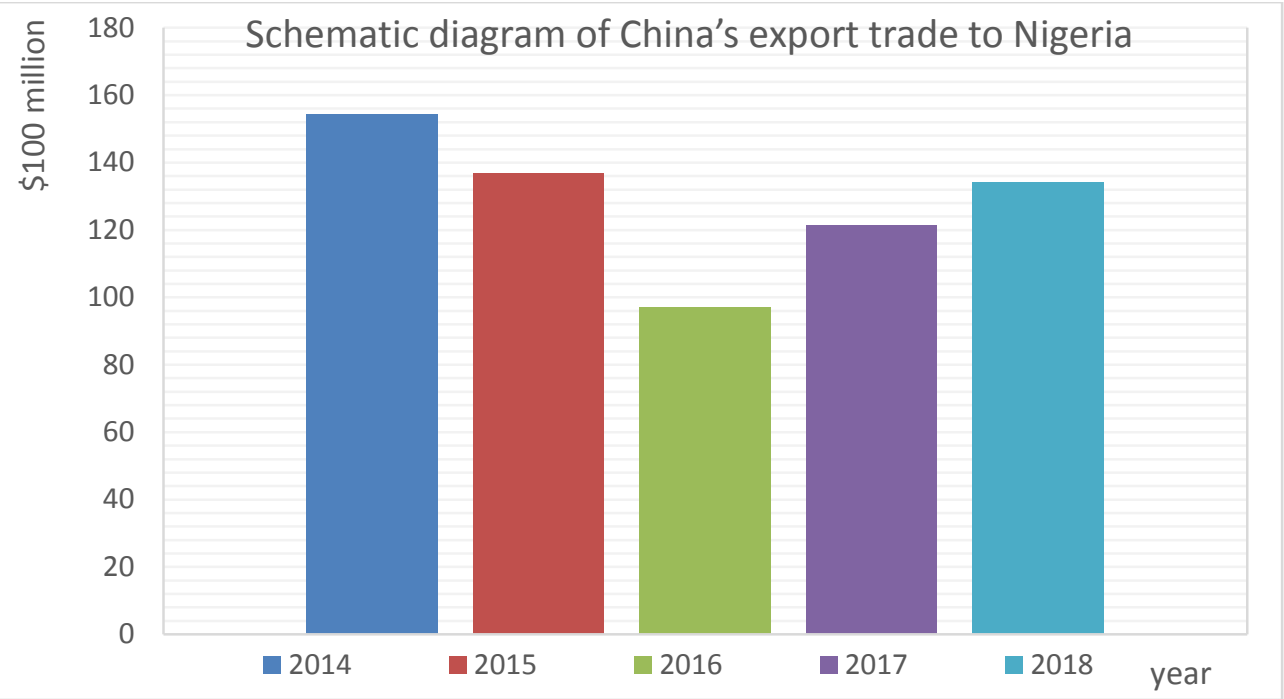

Fig 2:-Schematic diagram of China's export trade to Nigeria in recent years

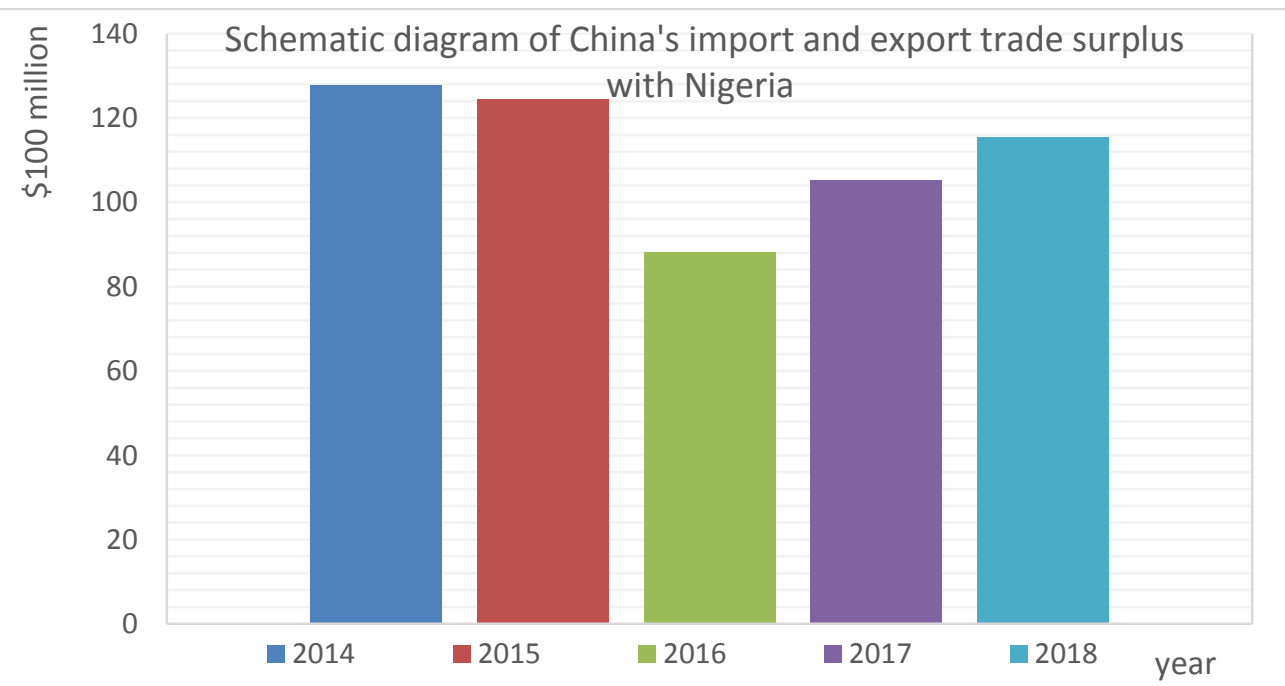

Fig 3:-Schematic diagram of China's import and export trade surplus with Nigeria in recent years 


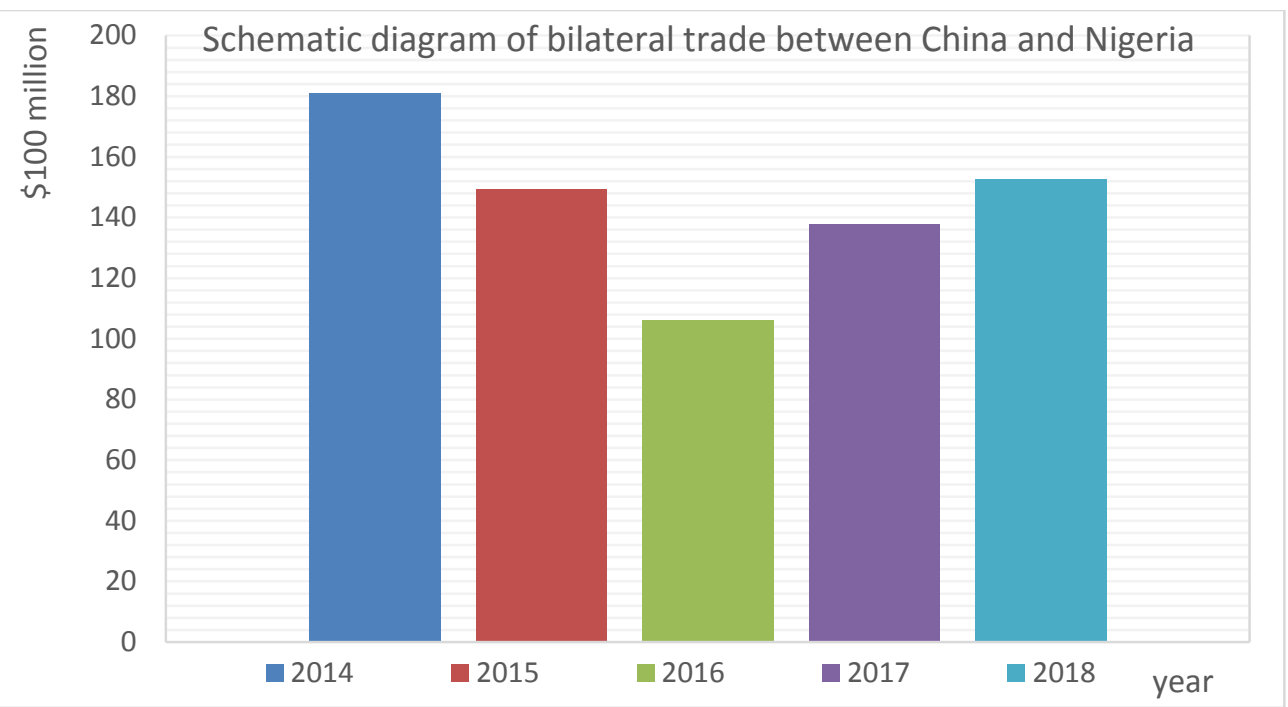

Fig 4:-Schematic diagram of bilateral trade between China and Nigeria in recent years

As can be seen from Figures 1 to 4, China- Nigeria trade reached the bottom in 2016, and it was settled in US dollar in 2014-2016. As the position of the US dollar in the market gradually declined, the trade volume between China and Nigeria declined overall. However, the bilateral trade volume between China and Nigeria increased gradually from 2016 to 2018, and the settlement currency changed from US dollar to RMB at this time. At the same time, RMB entered SDR, which promoted the international status of RMB and strengthened the confidence of Nigeria. And the overall trade volume has increased after the docking, which is more obvious than when the US dollar was used as an intermediate swap.

The impact on other African currencies under the docking of the RMB and Naira The Reference Significance of China- Nigeria Currency Exchange

As Nigeria continues to maintain the status of China's third-largest trading partner in Africa, only lower than South Africa and Angola, it continues to keep a high degree of cooperation. After the conversion of foreign trade currencies, more African countries have signed local currency swap agreements, and since then the RMB has become the international currency of Africa.

Today, Nigeria's central bank has deposited a large amount of RMB, while China's Industrial and Commercial Bank has deposited the same amount of Naira, and trade between China and Nigeria has been able to bypass the US dollar. Direct trade with Africa, and direct trade with Nigeria--a big African country whose population and GDP are the first in Africa, will further shake the dollar's position in Africa, making more African countries want to dock with the RMB.

\section{The status and influence of the RMB in Africa}

In recent years, China-funded commercial banks have established three new institutions in Africa, including the Sino-Congolese Bank for Africa which is a co-funded bank established by the Agricultural Bank of China and the Republic of Congo (Bulgaria) in 2015, the secondary branch of the China Construction Bank in Cape Town and the Luanda branch of the Bank of China in Angola in 2017. Overall, the Bank of China has set up seven institutions in Africa, the Construction Bank has set up two branches, the Industrial and Commercial Bank of South Africa has acquired 20\% stake in Standard Bank of South Africa and set up an African representative office in South Africa. The network layout of Chinese commercial banks in Africa is becoming more and more perfect. Financial services such as loans, trade financing, guarantees and so on are more diversified, which provides financial convenience for more local residents and enterprises. At present, the central banks of South Africa, Nigeria, Kenya, Tanzania, Ghana and Angola have incorporated the RMB into their foreign exchange reserves. The AfDB, the African Development Fund and the central banks of Mauritius, South Africa, Nigeria, Namibia and Mozambique have entered the interbank bond market of China. The AfDB and the African Development Fund are also preparing to invest in the Chinese banks and the foreign exchange market. 


\section{Conclusion:-}

Looking forward to the future, China and Africa have strong economic complementarities and great potential for cooperation. The RMB business has a large growth potential and broad development prospects in Africa. On the one hand, Africa has a realistic basis for conducting RMB business. All countries in the African continent are developing countries, there is an urgent need to develop infrastructure and manufacturing industries, and there is a great demand for China's products and services such as complete sets of equipment, project construction. At the same time, Chinese enterprises undertaking projects in Africa will also drive the demand for domestic equipment procurement. These needs have laid a good foundation for the use of RMB to carry out China-Africa trade and investment. On the other hand, with the deepening of Sino-African cooperation and the improvement of the international status of RMB, the acceptance of RMB in Africa will be further enhanced. African enterprises are more willing to accept, use and hold RMB subjectively from the perspective of saving exchange costs, reducing exchange rate risks and commercial risks.

The internationalization of RMB is a market-driven process, a natural process which will succeed when conditions are ripe. Next, we will continue to adapt to market demand and expand the use of RMB in Africa by improving the convenience of access to and use of RMB, so as to jointly promote the development of bilateral trade between China and Nigeria or other African countries.

\section{References:-}

1. Ma Guang-qi, Yao Yan. The Promotion Strategy of RMB from "Silk Road Currency" to "World Currency" under the"Belt and Road" Background[J]. ECONOMIST 2018(08):60-66.

2. Qiao Yide, Ge Jiafei. Reassessing RMB's Inclusion in the SDR Basket[J].International Economic Review 2015(3):35-45, 4-5.

3. Ikenna Henry Osuiwu, Research on China-Nigeria Economic and Trade Development[D].Anhui University, 201. 